\title{
PENGARUH ORIENTASI PEMBELAJARAN MOTIVASI KERJA DAN KOMITMEN TERHADAP KINERJA MADRASAH SWASTA
}

\author{
Lukman Hakim \\ IAIN Mataram NTB \\ e-mail: luxman2002@yahoo.com
}

\begin{abstract}
A combination of the research by Asatuan (2004) and Kiuk (2007), gave a model for empowerment to private institutions like madrasah to become qualified institutions that can take part in education development in order to educate people through learning orientation, motivation and commitment as well as to improve the performance of private madrasah. Applying the combination the two research scheme, this research aims to determine the influence of (1) orientation on performance of private madrasah, (2) motivation of working on performance of private madrasas, (3) commitment to the performance of the private madrasah. The results showed that (1) Learning orientation affect the performance of the private madrasah, (2) Motivation of working affected the performance of private madrasah, (3) Commitment affected to the performance of private madrasah.

Kombinasi penelitian yang dilakukan oleh Asatuan (2004) dan Kiuk (2007) memberikan model pemberdayaan bagi lembaga swasta seerti madrasah untuk menjadi lembaga yang bermutu yang dapat ikut ambil bagian dalam pembangunan pendidikan untuk tujuan mendidik masyarakat melalui orientasi pendidikan, motivasi, dan komitmen serta perbaikan kinerja madrasah. Dengan menggunakan kombinasi dua desain penelitian, penelitian ini bertujuan untuk menentukan pengaruh: (1) orientasi kinerja madrasah swasta; (2) motivasi kerja pada kinerja madrasah swasta; dan (3) komitmen terhadap kinerja madrasah swasta. Hasil dari penelitian ini menunjukkan: (1) Orientasi belajar mempengaruhi kinerja madrasah swasta; (2) Motivasi kerja mempengaruhi kinerja madrasah swasta; (3) Komitmen mempengaruhi kinerja madrasah swasta.
\end{abstract}

Keywords: madrasah swasta, orientasi pembelajaran, motivasi kerja, komitmen, kinerja 


\section{A. Pendahuluan}

Pendidikan Islam di Indonesia memang begitu dilematis, artinya di satu sisi tuntutan untuk meningkatkan mutu dan kualitas agar dapat bersaing dengan lembaga pendidikan umum, di sisi lain perhatian dari pemerintah terhadap lembaga pendidikan Islam masih rendah bahkan masih ditempatkan bukan sebagai kelas kedua (the second class). Sehingga peningkatan kualitas lembaga pendidikan Islam merupakan keharusan yang perlu segera direalisasikan, mulai dari input, proses dan output atau lulusan dari lembaga pendidikan Islam, SDM pengelola dan para pendidik memiliki peran penting dalam peningkatan kualitas lembaga pendidikan Islam.

Madrasah merupakan salah satu lembaga pendidikan Islam yang terintegrasi ke dalam Sistem Pendidikan Nasional sebagaimana ketentuan SKB 3 Menteri 1975 dan SKB 2 Menteri 1984. Sebagai bagian integral alam sistem pendidikan nasional tentunya madrasah memiliki posisi yang strategis. Posisi strategis madrasah dalam kenyataannya masih dihadapkan pada masalahmasalah fundamental seperti: (1) rendahnya persyaratan bagi pelaksanaan proses pendidikan yang berkualitas; (2) kurangnya kualitas dan sumberdaya lainnya yang memungkinkan peningkatan akses masyarakat terhadap pendidikan; (3) adanya ketidaksetaraan dalam pengembangan pendidikan terutama jika dibandingkan dengan sekolah umum. Secara spesifik ada tiga persoalan fundamental secara langsung berkaitan dengan rendahnya kualitas pendidikan, Pertama, rendahnya kualitas guru di madrasah. Kedua, rendahnya kemampuan manajemen madrasah. Ketiga, minimnya dukungan dari stakholders madrasah. Kondisi ini juga dihadapi oleh lembaga pendidikan madrasah negeri maupun swasta di daerah-daerah termasuk Kota Semarang. Oleh karena itu, madrasah swasta perlu meningkatkan memanajemen pengelolaan pendidikan yang orientasi pada pembelajaran, motivasi kerja, dan komitmen organisasi yang pada akhirnya dapat meningkatkan terhadap keberhasilan lembaga pendidikan madrasah swasta.

Orientasi pembelajaran adalah kegiatan apa saja yang menjadi sumber dari pembelajaran, dengan kata lain bahwa pembelajaran terletak pada kapabilitas/kemampuan dari sumber daya yang saling mengikat dalam perusahaan. Orientasi pembelajaran madrasah merupakan sasaran menuju hasil yang lebih baik sehingga madrasah perlu mengembangkan sumber daya yang 
sesuai dengan kemampuan madrasah. Begitu juga penelitian Johanis W. Kiuk mengatakan adanya hubungan antara orientasi pembelajaran dengan kinerja. ${ }^{1}$

Dalam penelitian Asatuan terdapat hubungan antara upaya kerja, dan prestasi kerja dan bahwa motivasi akan berpengaruh dalam membangkitkan, mengarahkan dan memelihara prilaku dengan lingkungan kerja untuk menghasilkan prestasi. ${ }^{2}$ Dengan demikian juka standard kerja, program kerja, sistem penghargaan baik berupa insentif finansial maupun karier dari manajemen madrasah ditentukan secara jelas, hal ini akan memunculkan motivasi bagi pegawai dan guru madrasah dalam peningkatan prestasi kerja. Begitu juga penelitian Asatuan yang mengatakan bahwa terdapat hubungan yang kuat antara motivasi kerja dengan kinerja. ${ }^{3}$

Dalam kontek berorganisasi, komitmen didefinisikan sebagai kekuatan relatif individu dalam melibatkan dirinya dengan lembaga pendidikan madrasah. Menurut Boyle komitmen dapat dikarakteristikkan dalam tiga dimensi, yaitu: (1) keyakinan yang kuat akan misi dan tujuan organisasi; (2) kemauan untuk berkorban demi tujuan organisasi; (3) Memiliki keinginan untuk membina hubungan jangka panjang dengan organisasi. Ketiga dimensi tersebut tidak hanya tampak dalam bentuk perilaku yang nyata namun juga perlu tertanam dalam perasaan. ${ }^{4}$ Sementara itu Mowday dalam Boyle, (1997) mengatakan komitmen sejati tidak hanya tampak dalam perilaku nyata, namun hendaknya benar-benar muncul dari kedalaman hati sehingga adanya komitmen dapat berpengaruh terhadap kinerja lembaga. ${ }^{5}$ Hal ini didukung oleh penelitian Johamis W Kiuk (2007) yang mengatakan bahwa adanya hubungan antara komitmen organisiasi dengan kinerja ${ }^{6}$

${ }^{1}$ Johanis W. Kiuk, "Marketing Strategy Making, Faktor, Proses dan Efektivitasnya," Jurnal Sains Pemasaran Indonesia, Vo.l I, No. 2, Program Magister Manajemen Fakultas Ekonomi UNDIP Semarang, 2007, h. 33-47.

${ }^{2}$ Asatuan, Agustina, “Studi Mengenai Pengelolaan Tenaga Penjualan,” Jurnal Sains Pemasaran Indonesia, Vol. III, No.1, Program Magister Manajemen Fakultas Ekonomi UNDIP Semarang, 2004, h. 25-37.

${ }^{3}$ Ibid.

4 Boyle, "International Law and the Environment," (Oxford: Oxford University Press, 1997), p. 146.

5 Ibid.

${ }^{6}$ Ibid. 
Penelitian ini merupakan eksistensi dari penelitian Asatuan dan Kiuk, sehingga kombinasi dari kedua penelitian digabung akan memberi model pemberdayaan lembaga madrasah yang berkualitas serta turut serta dalam menggerakkan pembangunan pendidikan dan mencerdaskan kehidupan masyarakat. Adapun perumusan masalah penelitian adalah bagaimana pengaruh orientasi pembelajaran motivasi kerja dan komitmen terhadap kinerja madrasah swasta.

\section{B. Orientasi Pembelajaran dan Kinerja}

\section{Orientasi Pembelajaran}

Orientasi pembelajaran menunjukkan bahwa kapabilitas organisasi yang mendasarkan pada asumsi lama di pasar yaitu perusahaan yang berfokus pada kejadian/perubahan lingkungan, yang mana akan mempengaruhi kemampuan perusahaan dalam memberikan kepuasan kepada pelanggan. ${ }^{7}$ Adanya perbedaan antara dua konsep yaitu orientasi pembelajaran tidak hanya mendasarkan pengetahuan pasar tapi juga memberi kepuasan pada pelanggan. Sedang Dodgson menyatakan bahwa orientasi pembelajaran dapat memudahkan suatu perusahaan untuk melakukan perubahan external secara efektif, misalnya pilihan pelanggan terhadap produk dan tehnologi. ${ }^{8}$ Pengembangan kapabilitas perusahaan akan mencakup organisasi untuk menyerap dan menggabungkan ide-ide baru. ${ }^{9}$ Kemudian Hurley and Hult mengingat kembali bahwa orientasi pembelajaran sebagai precursor dalam menjelaskan budaya perusahaan ke dalam inovasi. ${ }^{10}$

Adapun orientasi pembelajaran dalam penelitian ini diadopsi dari penelitian Calantone, et.al, yaitu suatu kegiatan organisasi dalam mengembangkan dan menggunakan pengetahan untuk meningkatkan keunggulan bersaing termasuk didalamnya empat komponen yaitu: berkomitmen dalam

\footnotetext{
7 Hardley, Mavondo, Felix T. \& Mark A. Farrell, "Measuring Market Orientation: Are There Differences Between Business Marketer's and Consumers Marketer's," Australian Journal of Management, September, 2000, p. 223-244.

8 Dodgson, et.al, "Self Esteem and Cognitive Accessibility of Strengths and Weekness After Failure," Journal of Personality and social Psychology, 1993, p. 178-194.

${ }^{9}$ Cohen, Aaron, "Relationship Among Five Forms of Commitment: an Empirical Assesment," Journal of Organizational Behavioral, Vol. 20, 1999, p. 238-308.

${ }^{10}$ Hurley, Robert F. \& G. Thomas M. Hult "Innovation, Market Orientation, and Organizational Learning: An Integration and Empirical Examination," Journal of Marketing, Vol. 62, 1998, p. 42-54.
} 
pembelajaran, berarti tingkat pembelajaran dalam organisasi disesuaikan dengan budaya, Pembagian visi, yaitu suatu organisasi dengan memfokuskan pada pembelajaran atau petunjuk dari organisasi, Keterbukaan, suatu keinginan dalam mengevaluasi kegiatan operasional rutin organisasi, serta mencari ide-ide baru serta pembagian pengetahuan antar funmgsi organisasi, yaitu dengan kepercayaan secara kolektif atau perilaku rutin yang berhubungan dengan kecepatan dalam belajar dengan unit lain yang berbeda dalam organisasi. ${ }^{11}$

\section{Motivasi Kerja}

Motivasi kerja dengan kinerja manajerial organisasi menarik perhatian para peneliti untuk mengungkapkan kebenaran hubungan antara kedua variabel tersebut. Konsep motivasi kerja adalah suatu proses yang mendorong orang/karyawan menggunakan kemampuan sepenuhnya untuk melakukan tugasnya. ${ }^{12}$ Kemampuan untuk mengerjakan tugas secara sungguhsungguh dipengaruhi oleh tingkat kebutuhan individu, karena adanya kebutuhan finansial dan kebutuhan ingin maju mencapai karier mendorong seorang karyawan ingin bekerja sungguh-sungguh agar mencapai hasil yang memuaskan. ${ }^{13}$

Motivasi seorang berawal dari kebutuhan, keinginan dan dorongan untuk bertindak demi tercapainya kebutuhan atau tujuan. Hal ini menandakan seberapa kuat dorongan, usaha, intensitas, dan kesediaanya untuk berkorban demi tercapainya tujuan. Dalam hal ini semakin kuat dorongan atau motivasi dan semangat akan semakin tinggi kinerjanya. Hal ini sesuai dengan pendapat Robbins yang menyatakan bahwa motivasi didefinisikan sebagai kesediaan untuk mengeluarkan tingkat upaya yang tinggi ke arah tujuan organisasi, yang dikondisikan oleh kemampuan upaya itu untuk memenuhi suatu kebutuhan individual. ${ }^{14}$

${ }^{11}$ Calantone, et.al, "A Comparation of Three Models to Explain Shop-Bot Use on The Web", Phsychology \& Marketing 11, 2000, p. 945-956.

12 Wilson E. O., Animal Communication, (Science Am: 1990), p. 52-60.

13 Bachroni, M., "Para Pelajar Sekolah Dasar yang Intelektualnya Superior Ditinjau dari Tingkat Pendidikan dan Jenis Pekerjaan Orangtuanya: Suatu Studi di Sekolah Dasar di Kodya Yogyakarta," Skripsi, (Yogyakarta: Fakultas Psikologi UGM, 1985), h. 67.

14 Robbin, Stephen P., Perilaku Organisasi: Konsep, Kontrocersi, Aplikasi, Jilid 1, Edisi Bahasa Indonesia, 1996, h. 89. 
Hubungan antara motivasi kerja dengan kinerja manajerial organisasi menarik perhatian para peneliti untuk mengungkapkan kebenaran hubungan antara kedua variabel tersebut. Konsep motivasi kerja adalah suatu proses yang mendorong orang/karyawan menggunakan kemampuan sepenuhnya untuk melakukan tugasnya. ${ }^{15}$ Kemampuan untuk mengerjakan tugas secara sungguh-sungguh dipengaruhi oleh tingkat kebutuhan individu, karena adanya kebutuhan akan finansial dan kebutuhan ingin maju mencapai karier mendorong seorang karyawan ingin bekerja sungguh-sungguh agar mencapai hasil yang memuaskan artinya komitmen yang ada dalam diri karyawan disebabkan oleh kewajiban-kewajiban pekerjaan mereka terhadap organisasi Seorang karyawan memiliki komitmen yang kuat disebabkan mereka merasa ingin melakukannya (normative commitment). ${ }^{16}$

\section{Komitmen}

Komitmen organisasional didefinisikan sebagai ukuran kekuatan identifikasi karyawan dengan tujuan dan nilai organisasi serta terlibat di dalamnya, komitmen oganisasi juga menjadi indikator yang lebih baik bagi karyawan yang ingin tetap pada pekerjaannya atau ingin pindah. ${ }^{17}$ Komitmen pada organisasi tersebut juga membahas kedekatan karyawan terhadap organisasi dimana mereka berada dan sekaligus komitmen merefleksikan kekuatan keterlibatan dan kesetiaan karyawan pada organisasi. Keterlibatan dan kesetiaan ini sangat dipengaruhi oleh seberapa besar pekerjaan yang dibebankan pada karyawan sesuai dengan harapan mereka. ${ }^{18}$

Menurut Robinson sebagaimana dikutip Babakus, et.al, komitmen organisasi dikatakan sebagai suatu keadaan atau derajat sejauh mana seseorang karyawan memihak pada suatu organisasi tertentu dengan tujuan-tujuannya, serta memelihara keanggotaan dalam organisasi itu. Konstruksi dari komitmen organisasi memusatkan perhatian pada kesetiaan individu atau karyawan

15 Wilson E. Animal Communication, pp. 52-60.

16 Bachroni, M., "Para Pelajar Sekolah Dasaryang Intelektualnya Superior...., h. 59.

17 McNeese Smith, Donna, "Increasing Employee Productivity, Job Satisfaction and Organizational Commitment," Hospital and Health Services Administration, Vol. 41, No. 2, Summer, 1993, p.p 160-175.

18 Babakus, Emin, Craven, David W., Johnston, Mark, dan Moncrief, William C., "Examining the Role of Organizational Variables in the Salesperson Job Satisfaction Model," Journal of Personal Selling and Sales Management, Vol. 16, Summer, 1996, pp. 33-46. 
terhadap organisasi atau perusahaan. Ini merupakan kondisi psikologi atau orientasi karyawan atau individu terhadap organisasi, dimana individu atau karyawan dengan senang hati tanpa paksaan untuk mengeluarkan energi ekstra demi kepentingan suatu organisasi atau perusahaan.19

Nyhan menyatakan bahwa komitmen karyawan pada organisasi disamakan dengan motivasi untuk memberikan layanan terhadap masyarakat karena komitmen pada organisasi dianggap sebagai komponen yang sangat bernilai bagi efektivitas organisasi, meskipun begitu para pengambil kebijakan belum banyak memberikan perhatian bagi terciptanya langkahlangkah strategis untuk meningkatkan komitmen karyawan pada organisasi juga belum ada kesadaran bahwa komitmen organisasi memegang peranan penting bagi kelangsungan suatu organisasi. ${ }^{20}$ Image yang berkembang terhadap pemerintah atas ketidakefisienan dan adanya perubahan yang sistematik merupakan suatu hal yang sangat penting ,manajer pemerintah biasanya menghadapi permasalahan yang sangat komplek sementara dana yang ada sangat terbatas disamping itu masyarakat mulai memiliki harapan yang tinggi terhadap kinerja pemerintah akibanya para manajer harus terus menerus melakukan suatu usaha untuk menciptakan strategi yang bisa memotivasi pegawai. Dengan motivasi tersebut diharapkan akan muncul peningkatan efektivitas dan produktivitas dalam unit kerja mereka. Beberapa ahli administrasi publik terkemuka mengutarakan suatu pandangan bahwa pembentukan komitmen organisasi merupakan kunci utama untuk menghadapi tantangan tersebut. ${ }^{21}$ Karenanya Nyhan menyarankan untuk meningkatkan komitmen organisasi agar terwujud peningkatan motivasi public service dan efektivitas organisasi. ${ }^{22}$

\section{Kinerja}

Menurut Prawirosentono kinerja adalah hasil kerja yang dapat dicapai oleh seseorang atau sekelompok orang dalam suatu organisasi, sesuai dengan

\footnotetext{
${ }^{19}$ Ibid.

${ }^{20}$ Nyhan Ronald, "Changing the Paradigm: Trust and Its Role in public Sector Organizations," American Review of Public Adminitration, 30 (1), 1999, p. 87-109.

${ }^{21}$ Golembiewski, Robert T, Public Administration as Developing Discipline, Part I: Perspeciti on Past and Present, (New York, 1985), p. 96; Nachmias, David, Research Methods in The Social Sciences. (St. Martin Press, 1996), p. 76-80..

${ }^{22}$ Nyhan Ronald, "Changing the Paradigm....."
} 
wewenang dan tanggung jawab masing-masing, dalam upaya mencapai tujuan organisasi bersangkutan secara legal, tidak melanggar hukum dan sesuai dengan moral maupun etika. ${ }^{23}$ Dengan mengacu pada pendapat Rue dan Byars ${ }^{24}$ serta Anthony dan Govindarajan, ${ }^{25}$ maka dalam penelitian ini, kinerja didefinisikan sebagai hasil akhir atau prestasi yang dicapai madrasah selama satu periode tertentu.

Pengukuran kinerja adalah pengukuran atas hasil dari implementasi strategi, dan hasil kinerja yang dianggap baik akan menjadi standar untuk mengukur kinerja di masa mendatang. Bila indikator yang menjadi ukuran kinerja meningkat, berarti strategi telah diimplementasikan dengan baik. ${ }^{26}$ Kaplan dan Norton mengembangakan tolok ukur kinerja perusahaan yang lebih komprehensif, dinamakan Balanced Scorecard (BS). ${ }^{27}$ Menurut konsep balanced scorecard kinerja perusahaan untuk mencapai keberhasilan kompetitif dapat dilihat dari empat bidang yaitu berdasarkan: (1) Perspektif finansial; (2) Perspektif pelanggan; (3) Perspektif proses bisnis internal serta (4) Perspektif pertumbuhan dan pembelajaran. Dalam penelitian ini, untuk mengukur kinerja madrasah swasta indikator yang digunakan adalah: (1) pertumbuhan jumlah murid; (2) tingkat kelulusan murid serta (3) prestasi murid. Berdasarkan penelitan terdahulu, penelitian ini dimaksudkan menguji kembali "Pengaruh Orientasi Pembelajaran, Motivasi Kerja dan Komitmen terhadap Kinerja Madrasah Swasta di Kota Semarang".

Untuk lebih jelasnya dapat dilihat model kerangka pemikiran pada gambar 1. Dari kerangka teoritis di atas maka diajukan hipotesis sebagai berikut:

Hipotesis 1 : Semakin baik orientasi pembelajaran, maka semakin baik kinerja madrasah swasta.

Hipotesis 2 : Semakin baik motivasi kerja, maka semakin baik kinerja madrasah swasta.

${ }^{23}$ Prawirosentono Suryadi, Kebijakan Kinerja Karyawan, (Yogyakarta BPFE, 1997), h. 2.

${ }^{24}$ Rue, L.W.\& Byars, L.L, Management, Skill \& Aplication, (Mc. Graw Hill Companies, 1997), p. 221.

${ }^{25}$ Anthony, Govindarajan, Banker, Robert Kaplan, Mark Young, Management Accounting, (New Jersey: Printice-Hill International. Inc., 1997), p. 441.

${ }^{26} \mathrm{Ibit}, \mathrm{h} .441$.

${ }^{27}$ Kaplan, Robert S dan David P. Norton, Balanced Scorecard: Translating Strategy Into Action, (Boston: Havard Business School Press, 1996), p. 76. 
Hipotesis 3 : semakin baik komitmen yang dilakukan, maka semakin baik kinerja madrasah swasta.

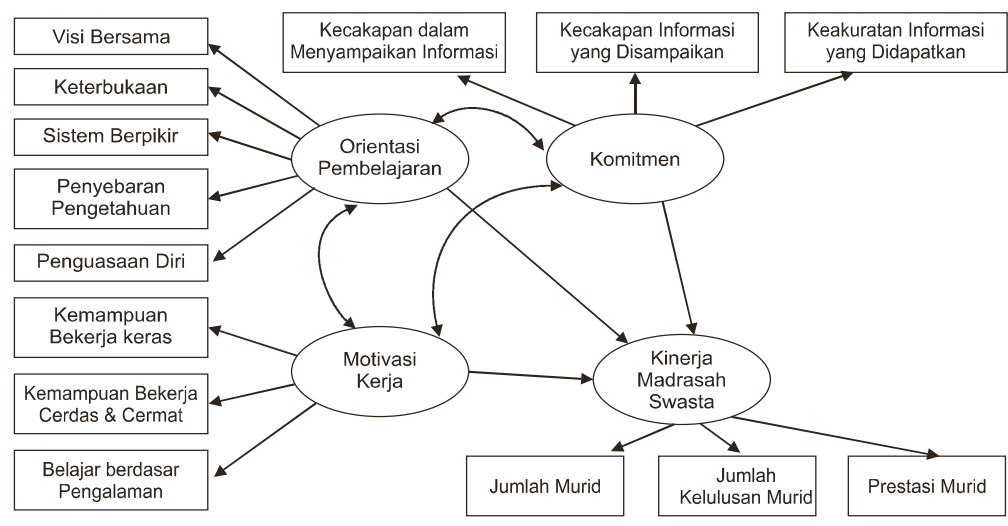

Gambar 1.

Kerangka Pemikiran Teoritis Penelitian

\section{Metode Penelitian}

Penelitian ini dilakukan pada lembaga pendidikan Islam (madrasah) baik MI, MTs mapun MA swasta di Kota Semarang. Jumlah madrasah (MI, MTs dan MA) swasta yang berjumlah 130 madrasah, terdiri dari 75 MI, 34 MTs dan 21 MA. Penelitian ini merupakan penelitian kausalitas yang menggunakan pendekatan kuantitatif dengan objek penelitian adalah orientasi pembelajaran, motivasi kerja, komitmen dan kinerja madrasah swasta. Sedangkan subjek penelitian adalah pengelola madrasah swasta yang terdiri dari kepala sekolah, guru dan tenaga administratif (tata usaha) pada madrasah swasta di Kota Semarang. Adapun metode pengumpulan data yang digunakan adalah metode survei dengan kuesioner baik secara langsung mendatangi responden. Penelitian ini menggunakan kepala sekolah, guru dan tenaga administratif madarasah swasta di Kota Semarang sebagai unit analisis. Instrumen yang digunakan adalah kuesioner. Kurun waktu (time horizon) yang diteliti adalah cross sectional yaitu hanya meneliti suatu waktu tertentu dengan banyak subjek (responden). 
Penelitian ini merupakan penelitian kausalitas yang menggunakan pendekatan kuantitatif dengan objek penelitian adalah orientasi pembelajaran, motivasi kerja, komitmen dan kinerja madrasah swasta. Adapun Metode pengumpulan data yang digunakan adalah metode survei dengan kuesioner baik secara langsung mendatangi responden.

Agar penelitian ini dapat dilakukan sesuai dengan yang diharapkan, perlu dipahami unsur-unsur yang menjadi dasar dari suatu penelitian ilmiah, yaitu konsep, variabel, sub variabel dan indikator empirik. Dalam penelitian ilmiah, suatu konsep akan dijabarkan kembali ke dalam suatu bentuk yang dapat dipahami dan diuji tingkat validitas dan reliabilitasnya. Agar konsep tersebut dapat diteliti secara empirik perlu dioperasionalisasikan dengan cara mengubah dan menjabarkannya menjadi suatu variabel atau sub variabel. Adapun operasionalisasi variabel penelitian dapat dijelaskan sebagai berikut: (1) Orientasi pembelajaran adalah suatu kegiatan organisasi dalam mengembangkan dan menggunakan pengetahan untuk meningkatkan keunggulan bersaing termasuk didalamnya empat komponen yaitu: (a) berkomitmen dalam pembelajaran, berarti tingkat pembelajaran dalam organisasi disesuikan dengan budaya; (b) Pembagian visi, yaitu suatu organisasi dengan memfokuskan pada pembelajaran atau petunjuk dari organisasi; (c) keterbukaan, suatu keinginan dalam mengevaluasi kegiatan operasional rutin organisasi, serta mencari ideide baru; (d) pembagian pengetahuan antar funmgsi organisasi, yaitu dengan kepercayaan secara kolektif atau perilaku rutin yang berhubungan dengan kecepatan dalam belajar dengan unit lain yang berbeda dalam organisasi; (2) Motivasi kerja adalah konsep motivasi kerja adalah suatu proses yang mendorong orang/karyawan menggunakan kemampuan sepenuhnya untuk melakukan tugasnya. ${ }^{28}$ Kemampuan untuk mengerjakan tugas secara sungguhsungguh dipengaruhi oleh tingkat kebutuhan individu, karena adanya kebutuhan akan finansial dan kebutuhan ingin maju mencapai karier mendorong seorang karyawan ingin bekerja sungguh-sungguh agar mencapai hasil yang memuaskan; ${ }^{29}$ (3) Komitmen adalah tekad bulat untuk melakukan sesuatu dengan niat yang sungguh-sungguh untuk melakukan. Komitmen pegawai pada suatu organisasi adalah suatu keadaan di mana karyawan memihak kepada organisasi tertentu dan tujuan-tujuannya, serta berniat memelihara keanggotaannya

\footnotetext{
28 Wilson E. O., Animal Communication.

${ }^{29}$ Bachroni, M., "Para Pelajar Sekolah Dasaryang Intelektualnya .....”
} 
dalam organisasi itu, dan (4) Kinerja merupakan suatu sistem atau metode yang berhubungan dengan aktivitas dengan hasil (outcome) yang diperoleh. Kinerja madrasah swasta merupakan sistem kerja yang berorientasi pada jumlah murid, tingkat kelulusan dan prestasi.

Instrumen yang digunakan adalah kuesioner. dari sumber data yang dikumpulkan secara khusus dan berhubungan dengan permasalahan yang diteliti. Jenis data ini diperoleh langsung dari penyebaran kuesioner atau daftar pertanyaan ke pada responden yang terpilih untuk penelitian ini. Adapun responden dalam penelitian ini adalah kepala sekolah, wakil kepala sekolah, guru dan karyawan (tata usaha) madrasah swasta di Kota Semarang. Adapun teknik analisidata yang digunakan adalah SEM.

\section{Model Structural Equation: Program AMOS}

Hasil komputasi data penelitian menyajikan model secara keseluruhan/ full model structural equation model dengan bantuan program Amos dapat jelaskan pada gambar4 berikut:

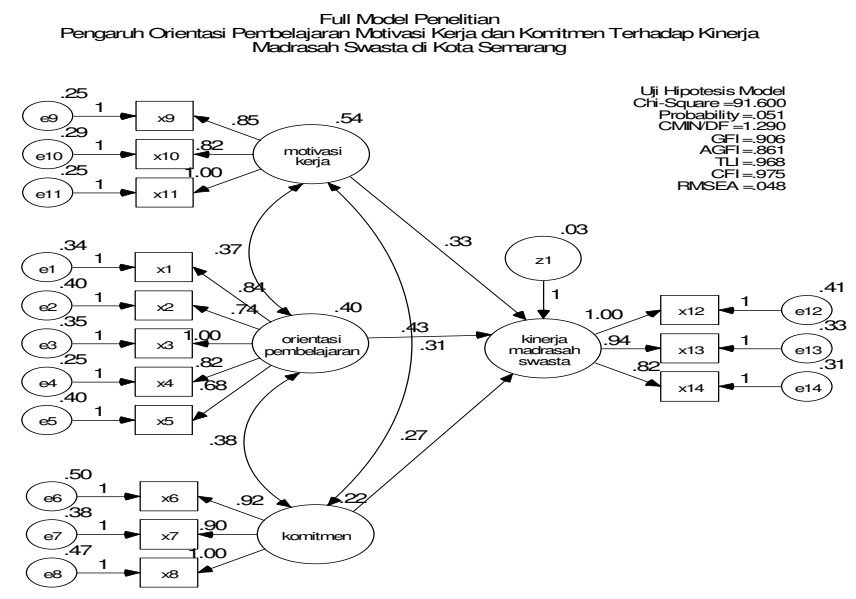

Gambar 2.

Full Model Structural Equation Model

Adapun hasil regression weight model penelitian dapat dijelaskan pada tabel berikut: 
Tabel 1.

Regression Weights: (Group Number 1 - Default Model)

\begin{tabular}{|c|c|c|c|c|c|c|}
\hline \multicolumn{3}{|c|}{ Hubungan antar Variabel } & \multirow{2}{*}{$\begin{array}{c}\text { Estimate } \\
0,433\end{array}$} & \multirow{2}{*}{$\frac{\text { S.E. }}{0,133}$} & \multirow{2}{*}{$\frac{\text { C.R. }}{3,259}$} & \multirow{2}{*}{$\frac{\mathbf{P}}{0,001}$} \\
\hline Kinerja madrasah swasta & $<-$ & $\begin{array}{l}\text { Orientasi } \\
\text { pembelajaran }\end{array}$ & & & & \\
\hline Kinerja madrasah swasta & $<-$ & Komitmen & 0,267 & 0,109 & 2,443 & 0,015 \\
\hline Kinerja madrasah swasta & $<-$ & $\begin{array}{l}\text { Motivasi } \\
\text { kerja }\end{array}$ & 0,331 & 0,125 & 2,651 & 0,008 \\
\hline
\end{tabular}

Sumber: Data penelitian diolah.

Pada tabel 1 tersebut dapat diketahui bahwa nilai CR sudah memenuhi kriteria, yaitu diatas 2 pada taraf signifikan 1\% dan nilai diatas 1,96 pada taraf signifikan $5 \%(0,05)$. Hasil uji goodness of fit measure untuk keseluruhan model yang telah direvisi disajikan pada tabel berikut:

Table 2.

Goodness of Fit Measure Model Penelitian

\begin{tabular}{lrl}
\hline \multicolumn{1}{c}{$\begin{array}{c}\text { Goodness of } \\
\text { Fit Index }\end{array}$} & $\begin{array}{c}\text { Cut-off value } \\
\text { Dihasilkan }\end{array}$ & Keterangan \\
\hline c2 Chi-square & 91,600 & Diterima \\
Significaned prob & 0,510 & Diterima \\
RMSEA & 0,048 & Diterima \\
GFI & 0,906 & Diterima \\
AGFI & 0,861 & Ditolak \\
CMIN/DF & 1,290 & Diterima \\
TLI & 0,968 & Diterima \\
CFI & 0,975 & Diterima \\
\hline
\end{tabular}

Sumber: Data penelitian diolah.

\section{Hubungan Orientasi Pembelajaran dengan Kinerja Madrasah Swasta}

Hasil penelitian menunjukkan bahwa semakin tinggi orientasi pembelajaran dari karyawan dan guru madrasah swasta maka akan menambah pengetahuan kerja yang berkaitan dengan kemampuan (skill) yang menunjang pekerjaannya. Hal tersebut akan memotivasi dirinya untuk bekerja lebih keras dan juga cerdas dalam meningkatkan kinerjanya pada akhirnya akan meningkatkan kinerja madrasah swasta. Sehingga dapat disimpulkan 
bahwa semakin tinggi orientasi pembelajaran maka semakin tinggi kinerja guru dan karyawan, hal akan berdampak positif terhadap peningkatan jumlah murid, peningkatan tingkat kelulusan murid dan peningkatan prestasi akademikaupun non akademik murid pada madrasah swasta.

Dengan melakukan orientasi pada pembelajaran seseorang akan cenderung untuk terus belajar dan untuk meningkatkan kemampuan melalui suatu proses pembelajaran dan menyerap pengetahuan dan keterampilan yang baru. Dengan adanya suatu keterampilan dan pengetahuan akan memudahkan seseorang untuk dapat beradaptasi dengan situasi. Demikian pula halnya dengan SDM (guru dan karyawan) di lingkungan madrasah swasta , dengan adanya suatu pengetahuan baru dan kemampuan yang baru yang bisa diterapkan dalam pekerjaan akan dapat mendorong guru dan karyawan madrasah swasta untuk bekerja dengan lebih baik dan efektif dari sebelumnya.

Hasil menunjukkan bahwa orientasi pembelajaran memiliki pengaruh yang signifikan dengan variable bekerja secara intelektual (working smart), dan bekerja secara intelektual memiliki pengaruh yang positip terhadap kinerja tenaga penjualan. Hasil yang dilakukan di beberapa penelitian yang berbeda belum menunjukkan dengan jelas hubungan yang terjadi antara variable kinerja tenaga penjualan terhadap efektivitas penjualan, sehingga terbuka untuk dilakukannya kritik secara terbuka dan membangun. Menurut Sujan etal dengan adanya orientasi pada pembelajaran seorang tenaga penjual akan lebih mudah beradaptasi dan merespon kondisi penjualan yang dihadapi dan mampu meningkatkan kinerjanya. ${ }^{30}$

Dalam konteks madrasah, dengan adanya orientasi pemebelajaran maka karyawan dan guru berorientasi pada peningkatan usaha untuk melakukan pekerjaan dengan persetujuan dari masing-masing fungsi/bagian, berusaha melakukan kegiatan dengan cara tidak takut dengan kritikan dan saran dalam mengembangkan lembaga, setiap melakukan pekerjaan dengan berpikir yang mudah untuk menyelesaikan, setiap pekerjaan yang baru baik dalam model/ rancangan desain maupun yang lain selalu berusaha menyebarkan pada karyawan dan guru lain serta pekerjaan yang dilakukan berusaha untuk me-

${ }^{30}$ Sujan, Harish, barton A. Weitz \& Nirmalaya Kumar), "Learning Orientation, Working Smart and Effective Selling," Journal of Marketing, Vol. 58, 1994, pp. 39-52. 
ngerjakan dengan hati yang senang/berusaha untuk dapat mengendalikan emosi diharapkan dapat meningkatkan murid, kelulusan dan prestasi murid. Kondisi ini akan lebih mudahkan madrasah swasta melakukan adaptasi dan merespon dengan baik sehingga pada akhirnya akan mampu meningkatkan kinerja madrasah swasta.

Hasil penelitian juga mendukung terhadap penelitian-penelitian terdahulu sebagaimana disebutkan oleh Baker \& Sinkula menunjukkan bahwa orientasi pemeblajaran secara signifikan berhubungan dengan kinerja perusahaan. ${ }^{31}$ Sedangkan Han etal menyatakan bahwa orientasi pembelajaran berpengaruh positif tetapi tidak signifikan terhadap kinerja perusahaan. ${ }^{32}$ Akan tetapi dalam penelitiannya tersebut dinyatakan bahwa orientasi pemeblajaran berpengaruh signifikan terhadap kinerja perusahaan, melalui inovasi sebagai variabel intervening. Lebih lanjut Lukas \& Ferrell menyatakan bahwa orientasi pembelajaran organisasi dianggap oleh peneliti sebagai kunci untuk menuju sukses organisasi di masa yang akan datang. ${ }^{33}$

Orientasi pembelajaran adalah kegiatan apa saja yang menjadi sumber dari pembelajaran, dengan kata lain bahwa pembelajaran terletak pada kapabilitas/kemampuan dari sumber daya yang saling mengikat dalam perusahaan. ${ }^{34}$ Orientasi pembelajaran madrasah merupakan sasaran menuju hasil yang lebih baik sehingga madrasah perlu mengembangkan sumber daya yang sesuai dengan kemampuan madrasah. Begitu juga penelitian Johanis W. Kiuk mengatakan adanya hubungan antara orientasi pembelajaran dengan kinerja. ${ }^{35}$

Baker dan Sinkula menyatakan terdapat hubungan yang positif dan signifikan antara orientasi pembelajaran dan kinerja perusahaan. ${ }^{36}$ Hal yang sama juga diungkapkan dalam penelitian Farrel (2000), Day (1994), Dickson

31 Yakni penelitian Chaston, et.al, (2001), Anderson \& Boocock (2002), Matlay (2000) dan Hardley \& Mavondo (2000), Narver \& Slater (1995), dalam Baker, William E., and Sinkula, James M.,

"The Synergistic Effect of Market Orientation and Learning Orientation on Organizational Performance," Journal of The Academy of Marketing Science, Vol. 27 No. 4, 1999, 411-427.

32 Han, Jin K., Kim, Namwoom, Srivastava, Rajendra K., "Market Orientation and Organizationa Performance: Is Innovation a Missing Link?," Journal of Marketing, Vol. 62, No. 4, October 1988, p. 16-30.

${ }^{33}$ Lukas, Bryan. A and Ferrell, O.C., "The Effect of Market Orientation on Product Innovation," Journal of the Academy of Marketing Science, Vol. 28, Spring 2000, p. 25-38.

34 Ibid.

35 Ibid.

${ }^{36}$ Baker, William E., and Sinkula, James M., "The Synergistic Effect of Market Orientation .... " 
(1996) dan Stata (1992) dalam Baker dan Sinkula. ${ }^{37}$ Sementara itu Hurley dan Hult menyatakan bahwa orientasi pembelajaran merupakan kunci keberhasilan suatu perusahaan. ${ }^{38}$ Perusahaan juga berusaha mempergunakan sumber daya yang dimilikinya untuk dapat berinovasi. Anggota organisasi perusahaan berusaha untuk belajar demi kemajuan perusahaannya. Berdasarkan penelitian Hurley dan Hult yang mengatakan adanya pengaruh yang positif antara pembelajaran organisasi dengan kinerja perusahaan. ${ }^{39}$

Jadi dapat disimpulkan bahwa jika madrasah swasta menerapkan orientasi pembelajaran dengan melibatkan seluruh warga sekolah (guru, karyawan, murid, orang tua murid) dalam pengambilan keputusan dan kebijakan atas persetujuan dari masing-masing fungsi/bagian madrasah, berusaha melakukan kegiatan dengan cara tidak takut dengan kritikan dan saran dalam mengembangkan madrasah, madrasah setiap melakukan pekerjaan dengan berpikir yang mudah untuk menyelesaikan, setiap pekerjaan yang baru baik dalam model/rancangan desain maupun yang lain selalu berusaha menyebarkan pada karyawan dan guru lain serta pekerjaan yang dilakukan berusaha untuk mengerjakan dengan hati yang senang/berusaha untuk dapat mengendalikan emosi dapat meningkatkan jumlah murid, meningkatkan jumlah kelulusan murid serta meningkatkan prestasi murid pada sekolah madrasah swasta. Oleh karena itu dapat disimpulkan bahwa orientasi pembelajaran berpengaruh yang signifikan dan positif terhadap kinerja madrasah swasta.

\section{Hubungan Motivasi Kerja dengan Kinerja Madrasah Swasta}

Hubungan antara motivasi kerja dengan kinerja berdasarkan hasil penelitian menunjukkan hubungan yang positif, artinya bahwa semakin baik motivasi kerja karyawan dan guru madrasah swasta maka semakin baik kinerja madrasah swasta, hal ini didukung oleh beberapa penelitian terdahulu. Menurut Amstrong hubungan antara motivasi dan kinerja adalah positif karena karyawan yang memiliki motivasi yang tinggi akan menghasilkan kinerja yang tinggi pula. ${ }^{40} \mathrm{Hal}$ ini berarti, semakin tinggi motivasi

37 Ibid.

${ }^{38}$ Hurley, Robert F. \& G. Thomas M. Hult, "Innovation, Market Orientation, and Organizational Learning: An Integration and Empirical Examination," Journal of Marketing, Vol. 62, 1998, p. 42-54.

39 Ibid.

${ }^{40}$ Armstrong, M., Manajemen Sumber Daya Manusia, (Jakarta: Media Kompetindo, 1994), h. 67. 
maka semakin tinggi pula kinerja karyawan. Kinerja karyawan pada akhirnya akan meningkatkan kinerja organisasi. Dalam penelitian Doyle dan Wong mengemukakan kaitan antara motivasi berprestasi dan kinerja. ${ }^{41}$ Doyle dan Wong menyebutkan bahwa kesuksesan suatu bisnis tidak terlepas dari besarnya motivasi yang muncul dalam pribadi karyawan. Semakin tinggi motivasi karyawan terhadap prestasi kerja maka semakin baik kinerja perusahaan..$^{42}$ Pendapat ini juga didukung oleh hasil penelitian sebelumnya yaitu penelitian yang dilakukan oleh Sukmawati S dan Djoko Susanto dalam Agus Sunarno dengan hasil penelitian menunjukkan bahwa hubungan antara motivasi kerja dan kinerja adalah kuat, dengan perolehan besarnya $\mathrm{R}=0,677$. Hal ini berarti bahwa semakin tinggi motivasi kerja Guru dapat berpengaruh positif bagi peningkatan kerjanya. ${ }^{43}$ Penelitian sebelumnya dilakukan pula oleh Bambang Setiaji dan Reni Ratnasari, dengan hasil penelitian menunjuk-

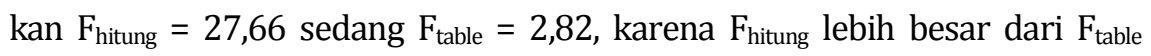
maka berarti motivasi kerja berpengaruh terhadap produktivitas kerja pegawai. ${ }^{44}$ Peningkatan produktivitas kerja pegawai akan berpengaruh terhadap kinerja organisasi. Penelitian berikutnya dilakukan oleh Ali Maftukin, dengan hasil penelitian menunjukkan bahwa Lingkungan Kerja, Sarana Prasarana dan Kemampuan Kerja secara bersama-sama berpengaruh positif terhadap Kepuasan Kerja Guru dibuktikan dengan $\mathrm{F}$ hitung lebih besar dari $\mathrm{F}$ tabel $(15,00077>1,49)$. Hal ini berarti motivasi kerja berpengaruh terhadap kinerja guru. ${ }^{45}$ Kinerja guru pada akhirnya akan meningkatkan kinerja sekolah.

Dalam penelitian Asatuan terdapat hubungan antara upaya kerja, dan prestasi kerja dan bahwa motivasi akan berpengaruh dalam membangkitkan,

41 Doyle, P. and Wong, V., "Marketing and Competitive Performance: An Empirical Study," European Journal of Marketing, Vol. 32, No. 5/6, 1998, p. 514-535.

42 Ibid.

${ }^{43}$ Agus Sunarno, "Pengaruh Motivasi Kerja, Kepemimpinan Kepala Sekolah dan Lingkungan Kerja terhadap Kinerja Guru (Suatu Studi Berdasarkan Persepsi Guru SMK Negeri Kota Tegal), Tesis, tidak dipublikasikan, (Surakarta: Program Pascasarjana Universitas Muhammadiyah Surakarta, 2005), h. 69.

44 Setiaji, Bambang dan Reni Ratnasari, “Pengaruh Kepemimpinan Demokratis, Motivasi dan Kualitas Komunikasi terhadap terhadap Produktivitas Kerja Pegawai pada Sekretariat Daerah Kabupaten Klaten 1970-1996," laporan penelitian, (Surakarta: Pascasarjana UMS, 2002), h. 68-75.

45 Ali Maftukin, "Pengaruh Lingkungan Kerja, Sarana Prasarana, dan Kemampuan Kerja terhadap Kepuasan Kerja Guru SMA di Kecamatan Gubug Grobogan,” Tesis, (Surakarta: Program Pascasarjana Universitas Muhammadiyah Surakarta, 2005), h. 89-95. 
mengarahkan dan memelihara prilaku dengan lingkungan kerja untuk menghasilkan prestasi. ${ }^{46}$ Dengan demikian juga standard kerja, program kerja, sistem penghargaan baik berupa insentif finansial maupun karier dari manajemen madrasah ditentukan secara jelas, hal ini akan memunculkan motivasi bagi pegawai dan guru madrasah dalam peningkatan prestasi kerja. Begitu juga penelitian Asatuan yang mengatakan bahwa terdapat hubungan yang kuat antara motivasi kerja dengan kinerja. ${ }^{47}$

Dari beberapa hasil penelitian di atas dapat disimpulkan bahwa motivasi kerja madrasah akan berpengaruh terhadap kinerja guru atau karyawan. Guru dan karyawan merupakan salah satu sumber daya manusia yang penting dan sangat berpengaruh terhadap mutu pendidikan madrasah. Guru dan karyawan adalah sosok yang mempunyai pengaruh dominasi dalam menentukan mutu pendidikan madrasah. Hal ini dapat dikaji dari guru dan karyawan itu sendiri antara lain dari faktor kualifikasi dan profesionalisme serta produktivitasnya. Produktivitas yang mantap akan mampu mendukung mutu pendidikan dan kinerja lembaga pendidikan Islam madrasah khususnya madrasah swasta. Oleh karena itu dapat disimpulkan bahwa dengan meningkatkan motivasi kerja baik guru dan karyawan pada madrasah swasta akan berpengaruh terhadap peningkatan jumlah murid, tingkat kelulusan murid dan prestasi murid, jadi motivasi kerja akan berpengaruh signifikan dan positif terhadap kinerja madrasah swasta.

\section{Hubungan Komitmen dengan Kinerja Madrasah Swasta}

Hubungan komitmen dengan kinerja berdasarkan hasil penelitian menunjukkan hubungan yang positif dan signifikan, artinya jika komitmen guru atau karyawan dengan memberi informasi yang cepat dalam menyampaikan informasi, memberi kecukupan informasi yang disampaikan pada murid serta memberi keakuratan informasi yang didapatkan dari murid akan berpengaruh terhadap kinerja madrasah melalui peningkatan pertumbuhan jumlah murid, tingkat kelulusan murid dan prestasi murid. Hasil penelitian dari Harrison dan Hubard menyatakan bahwa komitmen mempengaruhi outcomes (keberhasilan) organisasi. Kinerja karyawan dipengaruhi oleh

${ }^{46}$ Asatuan, Agustina, "Studi Mengenai Pengelolaan Tenaga Penjualan.”

47 Ibid. 
komitmen organisasional. ${ }^{48}$ Karyawan yang mempunyai keterlibatan tinggi dalam bekerja tidak mempunyai keinginan untuk keluar dari perusahaan dan dalam hal ini merupakan modal dasar untuk mendorong produktivitas yang tinggi. Pendapat tersebut didukung oleh Moncrief, etal yang mengungkapkan bahwa komitmen karyawan terhadap organisasi yang tinggi akan berpengaruh terhadap kinerja karyawan. ${ }^{49}$ Hasil studi McNeese Smith menunjukkan bahwa komitmen organisasional berhubungan signifikan positif yang ditunjukkan dengan nilai Pearson (r) sebesar 0,31 (signifikan pada level 0,001 ) terhadap kinerja karyawan. ${ }^{50}$

Menurut Morrison komitmen organisasional dianggap penting bagi perusahaan karena: (1) berpengaruh terhadap turn over karyawan; (2) berhubungan dengan kinerja yang mengasumsikan bahwa karyawan yang mempunyai komitmen terhadap perusahaan cenderung mengembangkan upaya yang lebih besar pada perusahaan..$^{51}$ Mowdey et.al mendefinisikan komitmen organisasional sebagai kekuatan relatif dari identifikasi individu dan keterlibatan dalam organisasi khusus, meliputi kepercayaan, dukungan terhadap tujuan dan nilai-nilai organisasi, dan keinginan yang kuat untuk menggunakan upaya yang sungguhsungguh untuk kepentingan organisasi, dan kemauan yang kuat untuk memelihara keanggotaan dalam organisasi. ${ }^{2}$ Komitmen organisasional menunjuk pada pengidentifikasian tujuan karyawan dengan tujuan organisasi, kemauan untuk mengerahkan segala upaya kepentingan organisasi dan keterikatan untuk tetap menjadi bagian organisasi. ${ }^{53}$

${ }^{48}$ Harrison, J. Klane and Russell Hubbard, "Antecedents to Organizational Commitment Among Mexican Employee of USA," 1998, p. 87-94.

${ }^{49}$ Moncrief, W.C, etal, "The Role Satisfaction With Territory Design on The Motivation, Attitudes, and Work Outcomes of Salespeople,"Journal of the Academy of Marketing Science. Vol. 29, No. 2, 2001, p. 165-178.

50 McNeese Smith, Donna,), "Increasing Employee Productivity, Job Satisfaction and Organizational Commitment," Hospital and Health Services Administration, Vol. 41, No. 2, Summer, 1993, h. 160-175.

51 Morrison, "How FranchiseJob Satisfaction and Personality Affects Performance, Organizational Commitment, Franchisor Relation, and Intention to Remain," Journal of Small Business Management, July, 1997, p. 78-99.

52 Mowdey, R.T., R.M. Steers and I. W. Porter, "The Measurement of Organizational Commitment," Journal of Applied Psychology, Vol. 84, 1979, p. 408-414.

53 Ibid. 
Berdasarkan hasil-hasil penelitian yang telah dilakukan menunjukkan bahwa antara komitmen organisasi dan prestasi kerja memiliki hubungan yang searah. Artinya, apabila komitmen organisasi yang dimiliki karyawan ti nggi, akan dapat meningkatkan prestasi kerja, demikian juga sebaliknya. Komitmen dapat terjadi karena adanya ketergantungan terhadap aktivitasaktivitas yang telah dilakukan dalam organisasi pada masa lalu dan ha1 ini tidak dapat ditinggalkan karena akan merugikan. Dengan kata lain, keinginan karyawan untuk bertahan dalam organisasi karena mereka merasa terlibat dan mengidentifikasikan dirinya dengan organisasi. Organisasi akan membuat karyawan memiliki keyakinan yang kuat untuk mengikuti segala nilainilai organisasi, dan berusaha untuk mewujudkan tujuan organisasi sebagai prioritas utama (affective commitment). Seseorang yang memiliki komitmen pada pekerjaan secara umum cenderung percaya bahwa kerja adalah pusat hidupnya. ${ }^{54}$ Komitmen karyawan untuk tetap bertahan di organisasinya karena karyawan tersebut takut akan kehilangan keuntungan-keuntungan finansial dan yang tidak diperoleh di tempat lain. Jadi, komitmen itu timbul lebih dikarenakan desakan ekonomi dan ketidakmampuan untuk mencari pekerjaan lain yang lebih baik (continuance commitment). Kreitner dan Kinicki berpendapat bahwa komitmen organisasi mencerminkan bagaimana seorang individu mengidentifikasikan dirinya dengan organisasi dan terikat dengan tujuan-tujuannya. ${ }^{55}$

Romzek menyebutkan bahwa peningkatan komitmen organisasi merupakan suatu hal yang sangat penting bagi motivasi dan kualitas pegawai yang bekerja disektor publik karena pelayanan publik membutuhkan tingkat komitmen yang baik apabila komitmen yang dimiliki seorang pegawai baik maka pelayanan publiknya juga baik begitu pula sebaliknya sedangkan pelayanan publik tersebut telah dipengaruhi oleh kultural yang ada. ${ }^{56}$ Sedang Meyer dan Allen, menyatakan bahwa pada dasarnya karyawan itu ingin berkontribusi untuk mencapai tujuan organisasi dimana untuk mencapai tujuan organisasi ini telah dipengaruhi oleh sifat komitmen yang berbedabeda, sehingga tuntutan tersebut diatas menjadi semakin mendesak pada saat fleksibilitas fiskal mulai menurun seperti sekarang ini, sementara

\footnotetext{
54 Ibid.

${ }^{55}$ Kreitner \& Kinicki, Perilaku Organisasi, Jil. I, (Jakarta: Salemba, 2003), h. 62-65.

56 Romzek, B.S., "The Effects of Public Service Recognition, Job Security, and Staff Reductions on Organizational Involvement," Public Administration Review, Vol. 45, 1985, p. 282-292.
} 
manajer pada lingkungan pemerintah memiliki kemampuan yang sangat terbatas untuk memberikan penghargaan ekstrinsik seperti promosi dan kenaikan gaji/pangkat. ${ }^{57}$

Komitmen organisasional dapat didefinisikan sebagai derajat seseorang mengidentifikasikan dirinya sebagai bagian dari organisasi dan berkeinginan melanjutkan partisifasi aktif di dalamnya. ${ }^{58}$ Sementara komitmen pada organisasi berhubungan langsung dengan kinerja dan tingkat absensi dan Benkhoff dalam penelitiannya menunjukan bahwa komitmen organisasi memegang peranan penting bagi peningkatan kinerja yang baik, karena dia mengatakan bahwa pengabaian terhadap komitmen pada organisasi akan menimbulkan suatu kerugian. ${ }^{59}$

Dalam penelitian terdahulu seperti yang disampaikan oleh Bill, Fullagar dan Clive dalam Muhadi telah menguji penelitian dengan memprediksi komitmen karyawan terhadap organisasi dan serikat pekerja studi ini didasarkan pada penelitian Porter dan Steer yaitu peranan komitmen organisasi pada perusahaan dan serikat pekerja, data diambil dari 100 karyawan yang menjadi anggota serikat pekerja dan diolah dengan analisis regresi. Hasil penelitian ini menujukan masa keanggotaan serikat pekerja merupakan karakteristik yang signifikan untuk memprediksi komitmen karyawan terhadap organisasi dan serikat pekerja. ${ }^{60}$ Adapun Mowdey etal telah menyatakan bahwa refleksi kekuatan keterlibatan dan kesetiaan karyawan terhadap organisasi, jika komitmen karyawan terhadap organisasinya tinggi maka akan berpengaruh terhadap kinerja, sedangkan kalau komitmen karyawan ini rendah maka pengaruh terhadap kinerja juga rendah bahkan dapat mengakibatkan munculnya keinginan untuk keluar.61 Sedangkan penelitian yang dilakukan

57 Meyer, J.P., Allen, N.J. \& Smith, C.A., “Commitment to Organizations and Occupations: Extension and Test of a Three-Component Conceptualization," Journal of Applied Psychology, Vol. 78 No. 4, 1993, p. 538-551.

58 Ibid.

59 Benkhoff, B, "Disentangling Organizational Commitmet: The Dangers of The Ocq for Research and Policy," Personel review, b, 26(1/2), 1997, p. 114-31

60 Muhadi, "Analisis Pengaruh Kepuasan Kerja terhadap Komitmen Organisasional dalam Mempengaruhi Kinerja Karyawan (Studi pada Karyawan Administrasi Univeristas Diponegoro)," Tesis, tidak dipublikasikan, (Semarang: Program Pascasarjana Universitas Diponegoro, 2007).

61 Ibid. 
oleh Benkhoff62 adalah bahwa hubungan antara komitmen karyawan terhadap organisasi dan kinerja menunjukan hasil yang signifikan antara keduanya. Tetapi ada juga yang mengatakan bahwa komitmen pada organisasi bisa merupakan konsekuen atau antecedent dari kinerja. ${ }^{63}$

Penelitian yang dilakukan Porter dan Steer juga menyatakan bahwa orang yang berkomitmen dengan organisasi ialah orang yang bersedia untuk memberikan sesuatu dari dirinya sebagai kontribusi bagi kebaikan organisasi jadi komitmen pada organisasi mempengaruhi kinerja. ${ }^{64}$ Jadi dapat disimpulkan bahwa dengan komitmen yang tinggi yang dilakukan madrasah swasta akan meningkatkan kinerja madrasah swasta. Hal ini sependapat dengan penelian Mowdey dalam Boyle, (1997), Farrel (2000), Day (1994), Dickson (1996) dan Stata (1992) dalam Baker dan Sinkula ${ }^{65}$ yang menyatakan bahwa komitmen sejati tidak hanya tampak dalam perilaku nyata, namun hendaknya benar-benar muncul dari kedalaman hati sehingga adanya komitmen dapat berpengaruh terhadap kinerja lembaga. Hal ini didukung oleh penelitian Johamis W. Kiuk yang mengatakan bahwa adanya hubungan antara komitmen organisiasi dengan kinerja organisasi.66

\section{E. Kesimpulan}

Orientasi pembelajaran, motivasi kerja dan komitmen bepengaruh pada kinerja madrasah swasta. Sedangkan orientasi pembelajaran merupakan faktor dominan yang mempangaruhi kinerja madrasah swasta, sehingga peran orientasi pembelajaran pada madrasah swasta perlu mendapat perhatian terutama dalam peningkatan orientasi pembelajaran yang berfokus pada pengembangan visi dan misi bersama antara guru, kepala sekolah,

${ }^{62}$ Benkhoff, B, “Disentangling Organizational Commitmet....”

${ }^{63}$ Muhadi, "Analisis Pengaruh Kepuasan Kerja...."

${ }^{64}$ Porter, L.W., Mowday, R., T., and Steers, R.M., Employee Organizational Linkages: The Psychology of Commitment, Absenteeism and Turnover, (New York: Academic Press, 1982), in Adam G. Alotaibi, 2001, "Antecedents of Organizational Citizenship Behavior: A Study of Public Personnel in Kuwait," Public Personnel Management, Vol. 30, No. 3 p. 363 - 376

${ }^{65}$ Baker, William E., and Sinkula, James M. " "The Synergistic Effect of Market Orientation and Learning Orientation on Organizational Performance,"

${ }^{66} \mathrm{Ibid}$. 
karyawan dan murid, keterbukaan dalam pengelolaan lembaga, Sistem berpikir rasional berdasarkan fakta dan data, penyebaran pengetahuan dan penguasaan diri pada guru, karyawan, kepala sekolah dan murid maka akan dapat meningkatkan kinerja madrasah swasta.[w] 


\section{BIBLIOGRAFI}

Sunarno, Agus, "Pengaruh Motivasi Kerja, Kepemimpinan Kepala Sekolah dan Lingkungan Kerja terhadap Kinerja Guru (Suatu Studi Berdasarkan Persepsi Guru SMK Negeri Kota Tegal)," Tesis, tidak dipublikasikan, Surakarta: Program Pascasarjana Universitas Muhammadiyah Surakarta, 2005.

Maftukin, Ali, "Pengaruh Lingkungan Kerja, Sarana Prasarana, dan Kemampuan Kerja terhadap Kepuasan Kerja Guru SMA di Kecamatan Gubug Grobogan," Tesis, tidak dipublikasikan, Surakarta: Program Pascasarjana UMS, 2005.

Armstrong, M., Manajemen Sumber Daya Manusia, Jakarta: Media Kompetindo, 1994.

Anthony, Govindarajan, Banker, Robert Kaplan, Mark Young, Management Accounting, New Jersey: Printice-Hill International, Inc., 1997.

Asatuan, Agustina, "Studi Mengenai Pengelolaan Tenaga Penjualan," Jurnal Sains Pemasaran Indonesia, Vol . 3, No. 1, Program Magister Manajemen UNDIP Semarang, 2004.

Babakus, Emin, Craven, David W., Johnston, Mark, dan Moncrief, William C, "Examining The Role of Organizational Variables in The Salesperson Job Satisfaction Model," Journal of Personal Selling and Sales Management, Vol. 16, Summer, 1996, p. 33-46.

Bachroni, M., “Para Pelajar Sekolah Dasar yang Intelektualnya Superior Ditinjau dari Tingkat Pendidikan dan Jenis Pekerjaan Orangtuanya: Suatu Studi di Sekolah Dasar di Kodya Yogyakarta," Skripsi, tidak dipublikasikan, Yogyakarta: Fakultas Psikologi UGM, 1985.

Baker, William E., and Sinkula, James M., "The Synergistic Effect of Market Orientation and Learning Orientation on Organizational Performance," Journal of The Academy of Marketing Science, Vol. 27 No. 4, 1999, 411-427.

Benkhoff, B, "Disentangling Organizational Commitmet: The Dangers of The Ocq for Research and Policy," Personel review, b, 26 (1/2), 1997, p. 114-131.

Boyle, International Law and the Environment, Oxford: Oxford University Press, 1997. 
Calantone, et.al, "A Comparation of Three Models to Explain Shop-Bot Use on the Web," Phsychology \& Marketing, Vol. 11, 2000, p. 945-956.

Cohen, Aaron, "Relationship Among Five Forms of Commitment: an Empirical Assesment," Journal of Organizational Behavioral, Vol. 20, 1999, p. 238-308.

Dodgson, etal, "Self Esteem and Cognitive Accessibility of Strengths and Weekness After Failure," Journal of Personality and Social Psychology, 1993, p. 178-194.

Doyle, P. and Wong, V., "Marketing and Competitive Performance: An Empirical Study," European Journal of Marketing, Vol.32, No. 5/6, 1998, p. 514-535.

Golembiewski, Robert T., Public Administration as Developing Discipline, Part I: Perspeciti on Past and Present, New York: 1985.

Han, Jin K., Kim, Namwoom, Srivastava, Rajendra K, "Market Orientation and Organizationa Performance: Is Innovation a Missing Link?" Journal of Marketing, Vol. 62, No. 4, October 1988, p. 16-30.

Hardley, Mavondo, Felix T. \& Mark A. Farrell, "Measuring Market Orientation: Are There Differences Between Business Marketer's and Consumers Marketer's," Australian Journal of Management, September 2000, p. 223-244.

Harrison, J. Klane and Russell Hubbard, "Antecedents to Organizational Commitment among Mexican Employee of USA," 1998.

Hurley, Robert F. \& G. Thomas M. Hult, "Innovation, Market Orientation, and Organizational Learning: An Integration and Empirical Examination," Journal ofMarketing, Vol. 62, 1998, p. 42-54.

Johanis W. Kiuk, "Marketing Strategy Making, Faktor, Proses dan Efektivitasnya," Jurnal Sains Pemasaran Indonesia, Vol. 1, No. 2, Program Magister Manajemen Fakultas Ekonomi UNDIP Semarang, 2007.

Kaplan, Robert S dan David P. Norton, Balanced Scorecard: Translating Strategy Into Action, Boston: Havard Business School Press, 1996.

Kreitner \& Kinicki, Perilaku Organisasi, Jil. I. Jakarta: Salemba, 2003.

Lukas, Bryan. A and Ferrell, O. C, "The Effect of Market Orientation on Product Innovation," Journal of The Academy of Marketing Science, Vol. 28, Spring, 2000, p. 25-38.

McNeese-Smith, Donna, "Increasing Employee Productivity, Job Satisfaction and Organizational Commitment," Hospital and Health Services Administration, Vol. 41 No. 2, Summer 1993, p. 160-175. 
Meyer, J.P., Allen, N.J. \& Smith, C.A., "Commitment to Organizations and Occupations: Extension and Test of a Three-Component Conceptualization," Journal os Applied Psychology, Vol. 78, No. 4, 1993, p. 538-551.

Moncrief, W.C, etal, "The Role Satisfaction With Territory Design on The Motivation. Attitudes, and Work Outcomes of Salespeople," Journal of The Academy of Marketing Science, Vol. 29. No. 2, 2001, p. 165-178.

Morrison, "How Franchise Job Satisfaction and Personality Affects Performance, Organizational Commitment, Franchisor Relation, and Intention to Remain," Journal of Small Business Management, July, 1997, p. 78-99.

Mowdey, RT., R.M. Steers and I.W. Porter, "The Measurement of Organizational Commitment," Journal of Applied Psychology, Vol. 84, 1979, p. 408-414.

Muhadi, "Analisis Pengaruh Kepuasan Kerja terhadap Komitmen Organisasional dalam Mempengaruhi Kinerja Karyawan: Studi pada Karyawan Administrasi Univeristas Diponegoro," Tesis, tidak dipublikasikan, Semarang: Program Pasjasarjana Universitas Diponegoro, 2007.

Nachmias, David, Research Methods in The Social Sciences, St. Martin Press, 1996.

Nyhan Ronald, Changing the Paradigm: Trust and Its Role in public Sector Organizations, American Review of Public Adminitration, 1999, p. 7-109.

Porter, L.W., Mowday, R., T., and Steers, R.M., Employee Organizational Linkages: The Psychology of Commitment, Absenteeism and Turnover, (New York: Academic Press, 1982), in Adam G. Alotaibi, "Antecedents of Organizational Citizenship Behavior: A Study of Public Personnel in Kuwait," Public Personnel Management, Vol. 30, No. 3, 2001, p. 363 - 376.

Prawirosentono Suryadi, Kebijakan Kinerja Karyawan, Yogyakarta, BPFE, 1997.

Robbin, Stephen P., Perilaku Organisasi: Konsep, Kontroversi, Aplikasi, Jilid 1, Edisi Bahasa Indonesia, 1996.

Romzek, B. S., "The Effects of Public Service Recognition, Job Security, and Staff Reductions on Organizational Involvement," Public Administration Review, 45, 1985, h. 282-292.

Rue, L.W.\& Byars, L.L, Management, Skill \& Aplication, Mc.Graw Hill Companies, 1997.

Setiaji, Bambang dan Reni Ratnasari, "Pengaruh Kepemimpinan Demokratis, Motivasi dan Kualitas Komunikasi terhadap Produktivitas Kerja Pegawai pada 
Sekretariat Daerah Kabupaten Klaten 1970-1996," laporan penelitian, tidak dipublikasikan, Surakarta: Pascasarjana Universitas Muhammadiyah Surakarta, 2002.

Sujan, Harish, Barton A. Weitz \& Nirmalaya Kumar, "Learning Orientation, Working Smart and Effective Selling," Journal of Marketing, Vol. 58, 1994, p. 39-52. 